Indexed by

\title{
Scopus \\ IMPROVING THE RELIABILITY OF DURABILITY PREDICTION OF BUILDING MATERIALS AND STRUCTURES AS ONE OF THE FACTORS OF SUSTAINABLE ECONOMIC DEVELOPMENT
}

Crossref

\section{Polivanova Tatyana Vladimirovna \\ Southwest State University, Faculty of construction and architecture, Department of heat and gas supply, Kursk, Russian Federation}

\section{Elena Mishchenko}

Tambov State Technical University, Institute of economics and life quality management, Tambov, Russian Federation

\author{
Urda Margarita Nikolaevna \\ Mordovia State University, \\ Southwest State University, \\ Law faculty, Department of \\ criminal law, \\ Kursk, Russian Federation
}

\author{
Apraksina Olga Nikolaevna \\ Tambov State Technical Uni- \\ versity, Institute of architecture, \\ construction and transport, \\ Department of construction of \\ buildings and structures, \\ Tambov, Russian Federation
}

\author{
Erofeev Aleksandr \\ Vladimirovich \\ Tambov State Technical Uni- \\ versity, Institute of architecture, \\ construction and transport, \\ Department of construction of \\ buildings and structures, \\ Tambov, Russian Federation
}

Key words: generalized Zhurkov equation, errors, durability prediction, thermal fluctuation concept, economic efficiency

doi:10.5937/jaes18-27931

Cite article:

Vladimirovna, T. P., Nikolaevna, M. U., Vladimirovich A. E., Mishchenko E., \& Nikolaevna O. A. [2020]. Improving the reliability of durability prediction of building materials and structures as one of the factors of sustainable economic development. Journal of Applied Engineering Science, 18(3), $463-466$.

Online aceess of full paper is available at: www.engineeringscience.rs/browse-issues 


\title{
IMPROVING THE RELIABILITY OF DURABILITY PREDICTION OF BUILDING MATERIALS AND STRUCTURES AS ONE OF THE FACTORS OF SUSTAINABLE ECONOMIC DEVELOPMENT
}

\author{
Polivanova Tatyana Vladimirovna ${ }^{1}$, Urda Margarita Nikolaevna ${ }^{2}$, Erofeev Aleksandr Vladimirovich ${ }^{3}$, \\ Elena Mishchenko ${ }^{*}$, Apraksina Olga Nikolaevna ${ }^{3}$
}

${ }^{1}$ Southwest State University, Faculty of construction and architecture, Department of heat and gas supply, Kursk, Russian Federation

${ }^{2}$ Mordovia State University, Southwest State University, Law faculty, Department of criminal law, Kursk, Russian Federation

${ }^{3}$ Tambov State Technical University, Institute of architecture, construction and transport, Department of construction of buildings and structures, Tambov, Russian Federation

${ }^{4}$ Tambov State Technical University, Institute of economics and life quality management ,Tambov, Russian Federation

During operation, building materials and structures in buildings and structures are exposed to a whole range of adverse effects, leading to the loss of their performance characteristics. It is shown that at present there is a possibility to predict the durability of building materials and structures already at the stage of their design without carrying out additional inspections during operation. This prediction is based on the concept thermal fluctuations destruction and deformation of the solid body. Experimental studies are presented to determine the effect of temperature and stress on the value of durability for polyvinyl chloride plates during cross bending, on the basis of which the thermal fluctuation constants of the generalized Zhurkov equation are found by three different methods. A comparative analysis of them is made and a method for their determination is proposed, which makes it possible to increase the accuracy of the durability prediction.

Key words: generalized Zhurkov equation, errors, durability prediction, thermal fluctuation concept, economic efficiency

\section{INTRODUCTION}

On the balance sheet of an enterprise there can be both circulating and fixed assets, which are understood as various tangible assets used for more than one year in the process of the organization's financial and economic activities, as well as administrative, socio-cultural and other types of activities [1]. Fixed assets are divided into production, which in turn are divided into active and passive fixed assets, and non-production. One of the main groups of passive fixed assets are buildings and structures that are characterized by high price.

\section{MATERIALS AND METHODS}

Buildings and structures consist of load-bearing and enclosing structures that are exposed to a whole range of both power loads and adverse effects of various nature (atmospheric, aggressive, etc.), leading to a decrease in their service life. The residual resource of buildings and structures in general, and building structures and materials in particular, is established during a survey, which can be carried out both in the form of a visual inspection of load-bearing structures (the presence of defects visible with the naked eye and their number is assessed), and with the help of instrumental control of destructive and non-destructive methods. The composition and fre- quency of inspections, including instrumental control, is determined by regulatory enactments and depends on the level of the structure, as well as on the conditions of its operation [2].

The current development of building science makes it possible to predict the service life (durability) of the structure at the design stage, knowing the operating conditions (stress-deformed state of the structure, loads, presence of adverse effects) and materials used. The exact time period of major maintenance, justified by the need to avoid structural failure (malfunction), will enable the organization to plan in advance the composition and scope of repairs or reinforcements, To lay down the required levels of financing for planned activities, and to optimize productive activities in the event that it is impossible to combine them with repairs [3].

A temperature-time dependence of strength makes it advisable to apply the thermoplastic concept of breaking and deformation of solids to predict the durability of building materials or structures, based on the concept of the critical role of the thermal motion of kinetic particles in the process of fracture (deformation). Durability together with reliability, serviceability are the characteristics of reliability [4-9].

In the thermo-fluorescence concept, body fracture is 
considered to be a thermo-excitation process that develops in time when applied to it by a load that reduces the energy of the bonds, which in turn leads to changes in the distance between the atoms. Consequently, with the increase of the mechanical field, there is an acceleration of the breaking of the interatomic or intermolecular bonds. The directionality of the applied load makes the process irreversible by accumulating elementary breaks.

The dependence of durability on operating stresses and ambient temperature is described by the generalized Zhurkov equation [10]:

$$
\tau=\tau_{m} \cdot \exp \left[\frac{U_{0}-\gamma \cdot \sigma}{R} \cdot\left(\mathrm{T}^{-1}-\mathrm{T}_{m}^{-1}\right)\right]
$$

which in the classical case includes four thermoplastic constants. These constants are determined by rearranging the graph of the coordinate logarithm time of the voltage into a graph, constructed at the coordinates of the logarithm time from the value of the return temperature of 1,000 times increased. The accuracy of the constant data determination depends directly on the reliability of the durability prediction. At the same time, the deviation from the forecast period, especially if the required repairs are to be carried out earlier than planned, will undoubtedly have a negative impact on the economic well-being of the enterprise.

The only possible way for producing the thermopluxation constants of the generalized Zhurkov equation at present is the experimental values of durability at certain stresses and temperatures. Hence, it is the experiment that is the main method of scientific knowledge in this case. Any experiment involves measurement errors, which by the nature of the occurrence are systematic, random and rough (misses), and by the method of measurement, the error of direct measurements, the error of indirectly reproducible and non-replicable measure- ments [11]. Any error occurring during the experiment, let alone their superimposition, causes the experimental durability values to deviate from their real values. Various statistical processing techniques are used to minimize the impact of errors on the final result. The application of different methods, as well as the level of relevance and confidence, can lead to different values of average durability, or more precisely logarithm, with an identical set of raw data. And taking into account that the method for determining thermopluxation constants involves working at semi-log coordinates, even minor errors in the area of small durability (experimental domain). In large extrapolations, the estimated service lives differ significantly from the real service life, which can be as long as several years or even decades. Although the method for determining thermopluxation constants is uniform, there are three possible ways of implementing it:

- graphical, in which the construction and reconstruction of graphs as well as all calculations are performed «manually»;

- graph-analytical, where coefficients are semi-automatic (graphs are constructed using specialized programs such as «Microsoft Excel»);

- mathematical, which is produced using a mathematical device, in particular the properties of a linear function.

Each of these methods has its own errors, which can lead to different outcomes when the source data set is identical.

The determination of the thermopluxation constants of the generalized Zhurkov equation of polyvinyl chloride plates at transverse bending in different ways based on experimental values of material durability [12] (Figure 1) at specified stresses and temperatures has shown: that the discrepancy $T_{m}$ is $15,5 \%,-\tau_{m} 1,7 \%,-U_{0} 17 \%$,

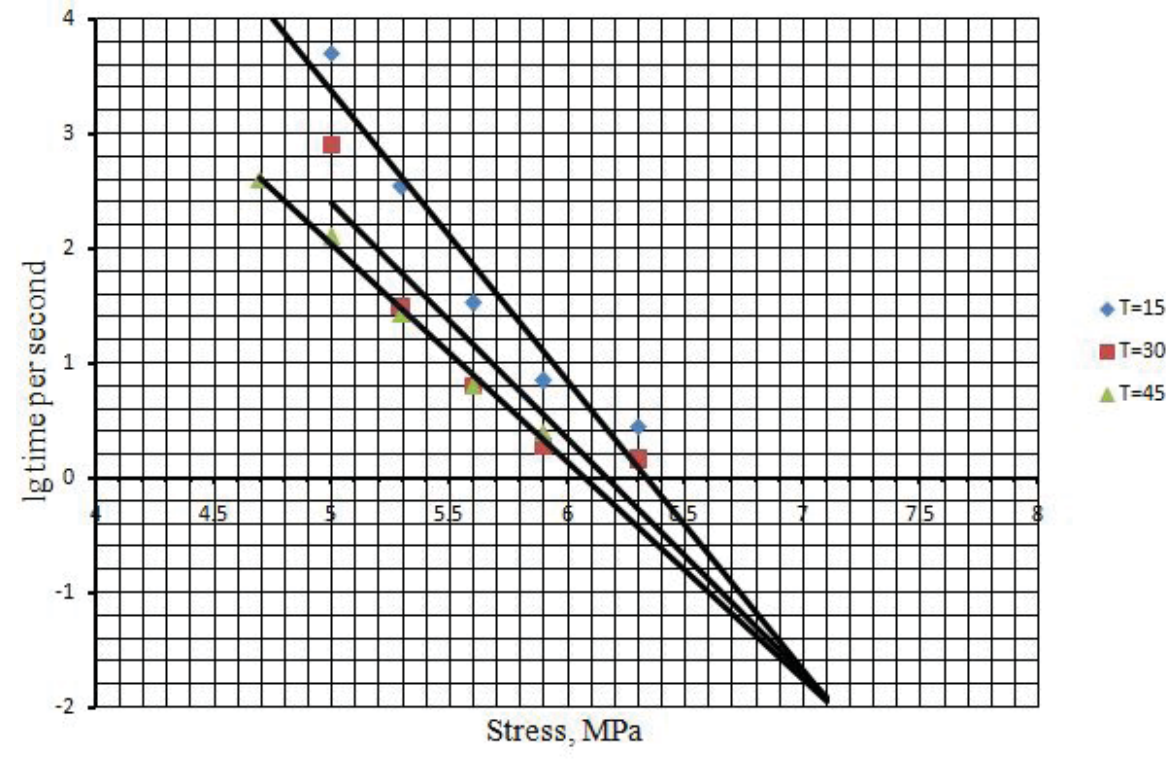

Figure 1: Dependence graph of the decimal logarithm of durability on voltage at a given temperature 
and $y-21 \%$. Determination of the thermopluxation constants of the generalized Zhurkov equation of polyvinyl chloride plates at transverse bending in different ways, based on the experimental values of material durability [12] (Figure 1). At certain stresses and temperatures, the value of the resultant thermofluodate constants is graphically dependent on the researcher's qualifications. The thermal fluctuation constants found by the methods are summarized in Table 1.

Thus, the deviation of the predicted service life from the real one when using various methods for determining the constants can range from several years to decades, depending on the voltage and operating temperature. It should also be noted that the thermal fluctuation constants obtained by a mathematical method give the greatest convergence with the initial data in the verification calculation of the material durability. In a mathematical calculation, the error is $5 . .15 \%$; with graphic-analytical, it reaches $170 \%$; and with graphical - up to $300 \%$. least 15 points at three different temperatures, with at least 6 tests per point required under similar conditions, which leads to a lot of work and accumulation of errors.

Based on the hypothesis that the change in the slope of the straight temperatures of the graph at the time logarithm coordinates of the voltage (Figure 1) is subject to a linear relationship and the possibility of determining the temperature of the existence of a solid body from the material derivative, It is possible to determine the remaining thermal fluorescence constants from a single line temperature and an additional point at a different temperature. For polyvinyl chloride plates, the thermopluxation constants found based on the above considerations are presented in Table 2.

Table 2: Thermal fluctuations constants

\begin{tabular}{|c|c|c|c|}
\hline$T_{m}, \mathrm{~K}$ & $T, \mathrm{c}$ & $U_{0}, \mathrm{~kJ} / \mathrm{mol}$ & $\gamma, \mathrm{kJ} / \mathrm{mol} \cdot \mathrm{MPa}$ \\
\hline 400 & 0,215 & 329 & 50 \\
\hline
\end{tabular}
At present, thermal fluorescence constants require at

Table 1: Summary table of found thermal fluorescence constants by different methods

\begin{tabular}{|c|c|c|c|c|}
\hline Method of Determination & $T_{m}, \mathrm{~K}$ & $T, \mathrm{c}$ & $U_{0}, \mathrm{~kJ} / \mathrm{mol}$ & $\gamma, \mathrm{kJ} / \mathrm{mol} \cdot \mathrm{MPa}$ \\
\hline Mathematical Method & 400 & 0,177 & 313,4 & 47,15 \\
\hline $\begin{array}{c}\text { Graphic-Analytical } \\
\text { Method }\end{array}$ & 431 & 0,011 & 327 & 48 \\
\hline Graphical Method & 390 & 0,18 & 370 & 58 \\
\hline
\end{tabular}

\section{CONCLUSIONS}

Analysis of the data in Tables 1 and 2 shows that while reducing labor costs for finding the thermal fluctuation constants, the obtained values correspond to the values obtained by the standard method.

Thus, the number of experiments is reduced by almost three times, which makes it possible to increase the number of studies conducted per point. At the same time, the labor input is still reduced and the reliability of the results is increased by reducing the number of operations and increasing the sample. As the reliability of the thermal fluorescence constants increases, so does the reliability of the durability prediction, and hence the timing of major repairs, which in turn increases the cost-effectiveness of long-term financial planning.

\section{REFERENCES:}

1. Sergeeva, T. YU. (2010). Osnovnye sredstva. Buhgalterskij i nalogovyj uchet: prakticheskoe posobie. Saratov, Aj Pi Er Media.

2. Volkov, A. A. (2015). Osnovy proektirovaniya, stroitel'stva, ekspluatacii zdanij i sooruzhenij: uchebnoe posobie. Moskovskij gosudarstvennyj stroitel'nyj universitet, EBS ASV.
3. Erofeev A.V. (2019). Nadezhnost' prognoza rabotosposobnosti stroitel'nyh materialov, izdelij i konstrukcij kak odin iz faktorov ekonomicheskoj bezopasnosti predpriyatiya. Strategii protivodejstviya ugrozam ekonomicheskoj bezopasnosti Rossii: materialy II Vserossijskogo foruma po ekonomicheskoj bezopasnosti. T. 2, p. 63-66

4. Dubrakova, O. K. [2019]. Optimization of thermal modernization of a group of buildings using simulation modeling. Journal of Applied Engineering Science, 17(2), 192-197.

5. Mamontov S.A., YArcev V.P., Monastyrev P.V. (2017) Iskusstvennoe i estestvennoe starenie drevesnovoloknistogo kompozita. Izvestiya vysshih uchebnyh zavedenij. Tekhnologiya tekstil'noj promyshlennosti, vol. 1 (367). 95-101.

6. Gusev B.V., Ezerskij V.A., Monastyrev P.V. (2005). Teploprovodnost' mineralovatnyh plit v usloviyah ekspluatacionnyh vozdejstvij. Promyshlennoe i grazhdanskoe stroitel'stvo, vol. 1, 48-49.

7. Gusev B.V., Ezerskij V.A., Monastyrev P.V. (2004) Izmenenie linejnyh razmerov mineralovatnyh plit $\mathrm{v}$ usloviyah ekspluatacionnyh vozdejstvij. Promyshlennoe i grazhdanskoe stroitel'stvo, vol. 8, 32-34. 
8. Monastyrev, P., Mischenko, E., Kuznetsova, N. (2018). Problems of Integration of Cultural Heritage Objects with Architectural and Historical Environment of the City. 2018 IOP Conf. Ser.: Mater. Sci. Eng. 463 032045, from https://doi.org/10.1088/1757899X/463/3/032045.

9. Pakhomova, E.G., Jezersky, V.A., Monastyrev, P.V., Kuznetsova, N.V. (2020). The choice of aversion of the project proposal on restoration of the cultural heritage property on the basis of multicriteria comparative analysis. IOP Conference Series: Materials Science and Engineering, 789(1), 012048, DOI: 10.1088/1757-899X/789/1/012048

10. Potapova, L.B. Mekhanika materialov pri slozhnom napryazhennom sostoyanii. Kak prognoziruyut predel'nye napryazheniya? M.: Izdatel'stvo Mashinostroenie -1 .
11. Sokova, S., Smirnova, N. (2019) The choice of durable blocking waterproofing mathematical method. Journal of Physics: Conference Series, no. 1425.

12. Drannikov, R.N. Opredelenie iskhodnyh dannyh dlya rascheta termofluktuacionnyh konstant obobshchennogo uravneniya ZHurkova polivinilhloridnyh plit. II Vserossijskaya (nacional'naya) nauchno-prakticheskaya konferenciya "Sovremennaya nauka: teoriya, metodologiya, praktika" 28 - 29 maya 2020 goda, Rossiya, Tambov. 